Bibliotech : Jurnal Ilmu Perpustakaan dan Informasi, 3 (2) 2018

\title{
PERSEPSI PUSTAKAWAN TERHADAP PERANNYA PADA LAYANAN REFERENSI: STUDI KASUS DI PERPUSTAKAAN HUKUM DANIEL S. LEV
}

\author{
Hammam Bagusni $^{1^{*}}$; Indira Irawati $^{2}$ \\ ${ }^{1,2}$ Universitas Indonesia
}

Korespondensi: hammam.bagusni@gmail.com

\begin{abstract}
ABSTRAK
Penelitian ini membahas persepsi pustakawan referensi mengenai perannya di Perpustakaan Hukum Daniel S. Lev. Tujuan penelitian ini untuk mengidentifikasi persepsi pustakawan mengenai peran dan kompetensinya dalam melayani pengguna yang membutuhkan informasi di bidang hukum melalui layanan referensi di Perpustakaan Hukum Daniel S. Lev beserta kendalanya. Penelitian ini merupakan penelitian kualitatif dengan menggunakan metode studi kasus. Hasil penelitian menunjukkan bahwa pustakawan memandang layanan referensi sebagai layanan substantif; pustakawan mempersepsikan perannya sebagai seorang library is a librarian, dan menjawab pertanyaan referensi dari pengguna yang bersifat research question, sementara ia pun juga memenuhi lima kompetensi profesional dari RUSA terlebih pada kompetensi akses, dasar pengetahuan, promosi dan kolaborasi. Kendala yang terjadi adalah, karena beban kerja dari pustakawan yang juga berlebih, maka perannya dalam melakukan pelayanan referensi masih belum berkembang hingga penciptaan produk baru secara signifikan, sementara itu staf layanan yang tersedia pun masih belum memiliki kompetensi yang cukup untuk diangkat dan didelegasikan menjadi seorang pustakawan referensi. Pada akhirnya peran pustakawan di Perpustakaan Hukum Daniel S. Lev dapat disimpulkan sebagai seorang "pustakawan aktivis" yang sibuk dalam organisasi profesi sebagai media untuk mengaktualisasikan dirinya dan bidang perpustakaan secara umum, yang membuat perannya pada layanan referensi menjadi tersisihkan.
\end{abstract}

Kata kunci: persepsi pustakawan; pustakawan referensi; layanan referensi; Perpustakaan Hukum Daniel S. Lev.

\section{PENDAHULUAN}

Layanan referensi atau rujukan merupakan ujung tombak dari sebuah perpustakaan yang dapat menjadi media 'penghantar' bagi pengguna dalam pemenuhan kebutuhan informasinya yang terdiri dari berbagai bidang atau pun subjek. Fungsinya adalah untuk memberikan bimbingan atau konsultasi terhadap pengguna yang membutuhkan efektivitas dan kesiagaan dalam mencari informasi yang berkaitan dengan kebutuhan dan minatnya secara spesifik, serta subjek yang relatif lebih luas seperti bahan bibliografis dan akses terhadap informasi elektronik, dengan cara mengajukan pertanyaan-pertanyaan berupa wawancara. Di dalam suatu layanan referensi terdapat tenaga ahli yang kompeten dan dikenal dengan sebutan pustakawan referensi yang berperan penting sebagai seorang 'mediator' antara pengguna dengan bahan informasi yang dibutuhkan. Dapat dikatakan pustakawan ini merupakan seorang yang berwawasan luas terhadap berbagai subjek yang terdapat pada koleksi referensi, maupun koleksi di perpustakaan secara umum. Interaksi secara intensif 
Bibliotech : Jurnal Ilmu Perpustakaan dan Informasi, 3 (2) 2018

dengan mengajukan pertanyaan terbuka dan tingginya kepekaan dalam membimbing pengguna dalam memenuhi kebutuhan informasinya merupakan aspek penting yang harus dilakukan oleh seorang pustakawan referensi.

Perpustakaan Hukum Daniel S. Lev (disingkat DanLev) merupakan perpustakaan khusus yang memiliki pengunjung atau pengguna yang secara aktual dan potensial terdiri dari peneliti yang berasal dari sekelompok komunitas hukum di Indonesia seperti praktisi hukum (advokat, hakim dan jaksa) serta aktifis yang memiliki urgensi terhadap informasi-informasi yang terkait dengan hukum, peraturan/perundang-undangan, putusan, dsb. Kebutuhan akan informasi khusus di bidang hukum membuat perpustakaan memerlukan sebuah jasa referensi yang dapat membantu pengguna dalam mencari serta memanfaatkan informasi dengan menggunakan sumber referensi ilmiah maupun koleksi referensi yang tersedia di perpustakaan dan di luar lingkup perpustakaan. Oleh sebab itu, murni dalam hal ini diperlukan keahlian dari pustakawan referensi yang memiliki ketertarikan dan pemahaman cukup dalam bidang ilmu hukum dan ilmu lainnya yang terkait, dimana informasi tersebut merupakan informasi yang relatif sensitif dan memang memerlukan penangan khusus dalam proses penyebarluasannya terhadap pengguna yang membutuhkan. Kemudian yang lebih pentingnya lagi adalah secara praktis pustakawan referensi paling tidak memiliki sejumlah kompetensi dasar pustakawan yang dapat menjadi acuannya sebagai staf khusus. Bahkan acuan ini 'tertuang' di dalam sebuah panduan profesional yang 'diorbitkan' oleh ALA pada tahun 2003, yakni RUSA (Reference and User Services Librarians) yang secara universal digunakan di dunia pustakawan internasional.

Pustakawan referensi yang bertugas di Perpustakaan Hukum Daniel S. Lev sendiri merupakan seorang yang juga merangkap sebagai kepala perpustakaan, dan memiliki banyak tanggungan pekerjaan baik secara internal maupun eksternal. Hal ini unik karena berbeda dengan pustakawan referensi yang berada pada perpustakaan lainnya di Indonesia yang notabene merupakan staf khusus tersendiri dan fokus pada tugas dan pekerjaan yang terkait dengan layanan referensi. Sehingga patut diketahui bagaimana kompetensi yang dimiliki olehnya sesuai aspek-aspek yang telah terstandarisasi dalam hal ini RUSA. Karena secara profesional, seperti yang telah dikemukakan sebelumnya bahwa kompetensi pustakawan referensi dapat dilihat dari panduan tersebut menyangkut sudah seberapa jauhkah pustakawan mendalami dan memahami perannya sebagai seorang yang memiliki kewajiban untuk melaksanakan layanan referensi di perpustakaan dalam hal ini yang bernaung di bidang hukum seperti Perpustakaan DanLev. Kemudian akan dicari tahu juga bagaimana staf layanan 
Bibliotech : Jurnal Ilmu Perpustakaan dan Informasi, 3 (2) 2018

dalam memandang pustakawan referensi menyangkut hubungan kerja, interaksi, dan tugastugas yang berkaitan dengan layanan referensi.

\section{METODE PENELITIAN}

Penelitian ini menggunakan pendekatan kualitatif dengan metode studi kasus. Studi kasus merupakan penelitian kualitatif yang menitikberatkan kepada suatu kasus pada kehidupan nyata yang memiliki batasan tertentu, dimana konteks dan keadaannya berfokus pada peristiwa kontemporer (Yin dalam Creswell, 2013, hlm. 97). Metode kualitatif studi kasus digunakan agar dapat mengidentifikasi dan mendeskripsikan peran pustakawan referensi di Perpustakaan Hukum Daniel S. Lev secara lebih terperinci. Informan dalam penelitian ini adalah pustakawan yang memiliki tugas dan kewajiban dalam melaksanakan pelayanan referensi di samping tugasnya sebagai Kepala Perpustakaan Hukum Daniel S. Lev, serta staf pustakawan yang bertugas di layanan perpustakaan secara umum yang memang memiliki kedekatan dengan informan kunci/utama dalam melaksanakan tugas atau pekerjaan di perpustakaan. Penarikan sampel dilakukan dengan cara snowball sampling. Teknik yang digunakan untuk mengumpulkan data dalam penelitian ini adalah dengan melakukan observasi dan wawancara mendalam terhadap subjek dari penelitian. Hasil dari pengumpulan data tersebut dianalisis melalui beberapa tahap, kemudian dideskripsikan dan diinterpretasikan pemaknaannya dalam pembahasan untuk selanjutnya ditarik menjadi sebuah kesimpulan penelitian.

\section{HASIL DAN PEMBAHASAN}

\subsection{Layanan Referensi: Tugas Penting yang Perlu Dilaksanakan}

Perpustakaan khusus merupakan suatu unit yang berada di lingkungan kerja lembaga, dengan jumlah sumber daya manusia atau pengelola yang sedikit atau bahkan mengandalkan pada satu figur (pustakawan), untuk melayani kebutuhan informasi dari banyaknya pengguna yang merupakan karyawan dari lembaga itu sendiri (Brophy, 2001). Tiap perpustakaan khusus pun memiliki layanan referensi masing-masing. Richard E. Bopp (2000), di dalam bukunya yang berjudul Reference and Information Services mendefinisikan bahwa layanan referensi adalah suatu layanan informasi di perpustakaan yang mencakup bimbingan pribadi, direktori, tanda-tanda, pertukaran informasi yang diambil dari sumber referensi, layanan konsultasi kepada pengguna, penyebaran informasi dalam mengantisipasi kebutuhan pengguna atau tujuan, dan akses menuju sumber informasi elektronik. Layanan ini dikembangkan karena memang bertugas untuk membantu pengguna perpustakaan yang ingin menemukan suatu 
Bibliotech : Jurnal Ilmu Perpustakaan dan Informasi, 3 (2) 2018

informasi yang dibutuhkannya secara cepat dan tepat dari koleksi yang ada di perpustakaan (Pedoman Umum Penyelenggaraan Perpustakaan Khusus, 2006). Menyesuaikan dengan perkembangan teknologi informasi pada perpustakaan, layanan referensi kini telah tumbuh secara virtual sebagai layanan yang dapat dijangkau melalui dunia maya tanpa harus datang secara langsung ke meja referensi di perpustakaan (J. Liu, 2007, hlm. 15).

Kegiatan layanan referensi di Perpustakaan Hukum Daniel S. Lev merupakan salah satu tugas yang saat ini diemban oleh informan sejak tahun 2010. Hal ini dikarenakan, secara konsep layanan ini memang masih menjadi tanggungjawabnya yang menjadi seorang pustakawan, dimana ia sebagai sosok yang paling menguasai dan memahami teori dalam melakukan pelayanan terhadap kebutuhan informasi dari pengguna yang secara spesifik terkait dengan bidang hukum. Tugasnya tersebut memang sesuai karena latar belakangnya yang merupakan sarjana ilmu perpustakaan. Sementara itu, informan lainnya terkadang juga secara teknis melakukan tugas pada layanan referensi. Meskipun sesungguhnya ia merupakan staf yang memiliki job desc di layanan (sirkulasi dan promosi) perpustakaan sejak ia bertugas di Perpustakaan Hukum Daniel S. Lev pada tahun 2015. Hal ini terjadi karena statusnya yang juga dianggap sebagai seorang assistant librarian, meskipun latar belakangnya adalah SMK dan masih menempuh studi S1 ilmu perpustakaan.

Layanan referensi di Perpustakaan Hukum Daniel S. Lev dikembangkan dengan mengusung konsep yang serupa dengan pengelolaan kearsipan yang terbagi kedalam dua golongan yakni layanan substantif dan administratif. Menurut informan pustakawan, layanan referensi digolongkan kedalam layanan substantif bersama dengan kemas ulang dan promosi, yang memiliki substansi dasar yang mana memiliki sebuah nilai jual informasi dan kemudahan akses terhadap informasi tersebut bagi pengguna yang membutuhkannya, untuk kemudian manfaatnya kembali lagi kepada perpustakaan itu sendiri. Sementara itu layanan seperti sirkulasi, jasa foto copy, atau alih media merupakan golongan dari layanan administratif, yang dikarenakan merupakan jenis layanan pada perpustakaan yang lebih menekankan kepada tugas-tugas pendataan (Wahyuni, 2015). Oleh sebab itu informan mempersepsikan serta memaknai bahwa esensi perpustakaan terkhusus pada layanan referensi pada saat ini adalah pada tugasnya yang harus memiliki akses yang luas untuk mendapatkan sumber informasi yang kaya dari tempat-tempat (perpustakaan) lainnya, tidak hanya yang dimiliki oleh perpustakaan sendiri saja. Layanan referensi juga diharapkan menjadi sebuah layanan yang berusaha untuk memberikan informasi secara cepat pada subjek yang spesifik kepada pengguna yang membutuhkannya. 
Bibliotech : Jurnal Ilmu Perpustakaan dan Informasi, 3 (2) 2018

Penggunaan layanan referensi virtual dapat dilakukan dengan berbagai jenis yakni berbasis e-mail, chat, dan telepon. E-mail reference adalah layanan referensi yang memiliki keutamaan untuk mengoleksi informasi dengan cukup karena akan sulit untuk dapat menemukan kembali informasi tersebut, menanyakan pertanyaan yang bersifat untuk mendorong (follow up), dan mendapatkan respon dari pengguna (Cassell dan Hiremath, 2009). Kelemahannya dalam layanan referensi e-mail adalah kurang mampu dalam membangun wawancara referensi secara efektif, serta nampak kurang serempak dan terlalu fokus kepada penyampaian pesan, sehingga menyebabkan jawaban yang diinginkan oleh pengguna tidak didapatkan dengan segera (Ross, 2002). Jenis yang kedua adalah layanan referensi berbasis chat dengan menggunakan aplikasi perangkat lunak khusus secara serempak. Jika ditinjau dari sisi pustakawan, layanan ini cukup sulit karena lingkungan referensi berbasis chat sendiri yang secara psikologis lebih menekan pustakawan untuk fokus menaruh perhatian dan merespon informasi yang dibutuhkan pengguna (J. Liu, 2007). Kemudahan yang didapatkan dari jenis ini adalah untuk mengajukan pertanyaan terhadap pustakawan referensi, pengguna hanya perlu chatting kemudian melakukan wawancara referensi, dan pada akhirnya mendapatkan respon menyangkut informasi dengan segera. Jenis lainnya selain dua jenis layanan referensi berbasis virtual diatas adalah referensi melalui telepon, dimana pustakawan dapat mendengar perubahan nada yang timbul dari suara percakapan pengguna dengan pustakawan referensi di telepon (Cassell dan Hiremath, 2009).

Sebagian besar layanan referensi di Perpustakaan Hukum Daniel S. Lev dilakukan secara virtual melalui beberapa media elektronik, seperti e-mail, chat via aplikasi media sosial WhatsApp Messenger menggunakan nomor pribadi informan, serta telepon. Ketiga media layanan referensi berbasis virtual ini dapat diakses oleh siapapun baik pengguna internal maupun pengguna eksternal perpustakaan, dan yang paling sering digunakan sebagai transaksi referensi di DanLev adalah e-mail dan chat. Menurut informan, melakukan layanan referensi secara virtual seperti e-mail dan khususnya telepon memang cenderung lebih sulit untuk memberikan bukti konkret dari bentuk koleksi atau bahan yang kontennya mengandung informasi yang dimaksudkan tersebut. Kesulitannya adalah, informan masih memerlukan waktu yang cukup lama untuk mengetikkan kalimat perkataan yang sedang ditanyakan pengguna ketika terjadi transaksi referensi di e-mail atau melalui WhatsApp Messenger agar tidak terjadi kekeliruan dalam memberikan suatu informasi. Oleh karena itu, pelayanan referensi lebih nyaman dilakukan secara langsung karena informasi yang sedang dibutuhkan oleh pengguna dapat diklarifikasikan dan dipahami secara lebih jelas dan tidak memakan waktu. 
Bibliotech : Jurnal Ilmu Perpustakaan dan Informasi, 3 (2) 2018

\subsection{Peran dan Kompetensi Sebagai Pustakawan Referensi}

Informan sebagai seorang pustakawan referensi setidaknya memiliki peran sebagai seseorang yang dapat menjembatani informasi terhadap pengguna yang menggunakan layanan referensi. Mengingat bahwa Perpustakaan Daniel S. Lev merupakan perpustakaan yang bergerak di bidang hukum, maka otomatis diperlukan kompetensi dalam memahami berbagai subjek yang berkaitan dengan bidang ilmu hukum. Oleh karena itu, informan berperan dalam menangani penelusuran terhadap subjek yang lebih mendalam dan butuh analisis lebih lanjut. Informan dalam hal ini melakukan kegiatan research question yang mana seorang pustakawan referensi memberikan informasi lainnya dengan melalui konsultasi mengenai kebutuhan informasi yang sudah lebih kompleks dan spesifik (Bopp, 2000). Sementara itu, untuk pertanyaan yang sifatnya masih sederhana seperti ready-reference question, sebagian besar pertanyaan yang masuk adalah pertanyaan yang bersifat mencari subjek yang lebih umum seperti mendapatkan sebuah buku, atau koleksi-koleksi lainnya yang terkait dengan bidang hukum. Pengerjaannya pun dapat dilakukan oleh kedua informan, dengan cukup menjawab pertanyaan sederhana dengan menggunakan sumber yang tersedia baik di perpustakaan sendiri maupun lain secara cepat.

Pelaksanaan layanan referensi pada suatu perpustakaan tidak terlepas dari kegiatankegiatan yang lebih difokuskan secara spesifik untuk melayani pengguna yang membutuhkan penanganan tertentu terhadap informasi. Oleh sebab itu, perannya yang vital seringkali membuat layanan referensi menjadi ujung tombak dari sebuah layanan perpustakaan, tidak terkecuali di perpustakaan khusus. Menurut Bopp (2000), terdapat tiga bentuk kegiatan dasar yang idealnya dilakukan pada layanan referensi dimanapun perpustakaan tersebut bernaung. Bentuk kegiatan atau layanan yang pertama dalam layanan referensi adalah layanan informasi (information services yang contohnya adalah ready-reference question, bibliographic verification, interlibrary loan and document delivery, information and referral service, research questions, dan fee-based services and information brokering. Sementara itu, bentuk kegiatan kedua yang dapat dilakukan pada layanan referensi adalah melakukan bimbingan (guidance), seperti readers' advisory services, biblioteraphy, term-paper counseling, dan selective dissemination of information. Bentuk kegiatan layanan referensi yang terakhir adalah kegiatan instruksi (instruction) atau Literasi Informasi yang dapat dikategorikan kedalam dua jenis yakni one-to-one instruction dan group instruction.

Katz (1992) di dalam bukunya yang berjudul Introduction to Reference Work vol. 1 , sixth edition, mengatakan bahwa pustakawan referensi merupakan kunci dari layanan 
Bibliotech : Jurnal Ilmu Perpustakaan dan Informasi, 3 (2) 2018

referensi, seorang pustakawan yang sesungguhnya, dimana ia memiliki tanggung jawab dalam menginterpretasikan pertanyaan, mengidentifikasi ketepatan sumber informasi yang akan menjadi jawaban, dan memutuskan apakah respon yang diberikan telah mencukupi atau tidak. Kemudian pustakawan referensi juga dapat disebut sebagai seorang mediator yang menjadi penghubung antara pengguna, dengan sumber informasi yang sedang dibutuhkan. Sehingga pustakawan referensi pun perlu memiliki karakter-karakter profesional seperti tingkat kedisiplinan/kefokusan diri, niat untuk membantu, peka terhadap kebutuhan orang lain, kesabaran, wawasan yang luas dan mendalam, serta pengetahuan mengenai sumber-sumber referensi (Bopp, 2000). Menurut Cassel dan Hiremath (2009), seluruh pustakawan referensi setidaknya harus memiliki keterampilan untuk membantu pengguna dalam menemukan informasi dan menjawab secara cepat, serta selalu siap sedia untuk mengajarkan pengguna bagaimana cara untuk menggunakan sumber referensi yang tersedia di perpustakaan.

Prinsip yang diusung oleh informan dalam melakukan pelayanan referensi di Perpustakaan Hukum Daniel S. Lev adalah library is a librarian, yang berarti adalah pustakawan merupakan perpustakaan itu sendiri. Pengguna yang mayoritas merupakan praktisi di bidang hukum ataupun peneliti tidak selalu datang ke tempat/perpustakaan secara langsung, namun hanya perlu menghubungi informan sebagai pustakawan referensi di Perpustakaan Hukum Daniel S. Lev. Hal ini dikarenakan layanan referensi di perpustakaan ini yang tidak memiliki meja referensi secara khusus, sehingga informan pun biasa menjawab pertanyaan pengguna dari meja kerja nya yang berada di pojok ruang perpustakaan, atau bahkan ketika berada di luar perpustakaan secara virtual. Oleh karena itu, informan memiliki peran yang penting terkait kompetensinya sebagai seorang pustakawan referensi dalam melayani, serta proses dalam melakukan pencarian hingga penyajian terhadap informasi yang dibutuhkan tersebut. Menurut informan, pustakawan referensi adalah seorang individu yang memiliki kemampuan analisis dalam menentukan dan memahami subjek-subjek informasi yang dibutuhkan. Sebuah profesi yang membutuhkan keseimbangan antara keterampilan dalam melakukan sesuatu dengan teknik tertentu dan tahan terhadap rutinitas, serta intelektualitas dalam melakukan pekerjaannya di lapangan seperti melakukan penelusuran, menentukan kata kunci, mengetahui database yang sedang berkembang, dan memberikan informasi baru yang jauh lebih spesifik.

Persepsi merupakan proses penangkapan informasi secara sensorik atau penginderaan seperti melihat, mendengar, merasakan, mencium, dan meraba berbagai objek yang terdapat di dunia yang menjadi ruang lingkup kehidupannya yang dapat menjadikannya sebuah stimulasi kesadaran dalam membimbing tiap-tiap individu (Blake dan Sekuler, 2006). 
Bibliotech : Jurnal Ilmu Perpustakaan dan Informasi, 3 (2) 2018

Terdapat tiga faktor yang berperan ketika manusia mempersepsikan sesuatu, yakni adanya objek, adanya alat penginderaan, serta adanya perhatian dari individu (Walgito, 1988). Seorang individu seperti contohnya seorang pustakawan yang memiliki kemampuan untuk mempersepsikan dirinya sendiri atau menjadikan dirinya sebagai objek persepsi berdasarkan pengalaman dan aktivitas inderawi yang ia lakukan disebut juga sebagai persepsi diri atau self-perception.

1. Memberikan Akses yang Mudah dan Terjangkau

Erat kaitannya dengan sikap responsif yang dilakukan pada layanan referensi, informan menitikberatkan bahwa pustakawan referensi yang memiliki kewajiban dalam melayani pengguna perlu untuk memiliki kemampuan dalam mengakses, menelusur informasi yang terkait dengan bidang hukum, serta menyampaikan dan menjawab kemauan pengguna dengan pembawaan sikap yang sabar (patience). Ketika seorang pustakawan referensi telah terbiasa dengan kebiasaan menelusur, mencari tahu informasi, maka ia pun sudah akan mengenal sumber dan bahan apa saja yang dapat dijadikan acuan ketika ingin menjawab pertanyaan referensi dengan cepat. Sebagai pustakawan referensi, informan perlu untuk memperhatikan segala bentuk perkataan yang ia komunikasikan kepada pengguna secara hati-hati. Oleh sebab itu, dalam melakukan komunikasi informan perlu untuk menyesuaikan dengan kata-kata yang biasa digunakan oleh pengguna, yang mana hal tersebut lebih mudah dipahami olehnya. Komunikasi yang dilakukan tersebut juga terkait dengan kesadaran yang merupakan bentuk dari kepekaan (sensitivity) terhadap pengguna.

Ketika merespon kebutuhan pengguna pun pustakawan referensi juga perlu menunjukkan sikap yang bersahabat, serta kemampuan dalam memahami kata per kata yang dituliskan dalam chat dan menggali kebutuhan pengguna dengan cara bertanya. Hal ini merupakan bagian dari kemampuan approachability dan listening and inquiring dari pustakawan referensi (Ronan, 2003). Motivasi, merupakan sebuah ide yang terbentuk karena adanya dorongan dan kemauan untuk bertindak secara sungguh-sungguh dari pustakawan referensi tersebut untuk selalu mengulurkan bantuan bagi pengguna yang memang kesulitan dalam melakukan pencarian informasi. Aspek-aspek ini pun juga terkait dengan sikap disiplin (discipline), yang mana pustakawan referensi perlu fokus terhadap apa yang sedang dibutuhkan pengguna, dan bagaimana cara untuk memberikan solusi dari hal tersebut dengan mengkomunikasikannya menggunakan berbagai teknik. Informan menganggap bahwa dalam melakukan layanan referensi perlu ada rasa sungguh-sungguh yang timbulnya 
Bibliotech : Jurnal Ilmu Perpustakaan dan Informasi, 3 (2) 2018

dari diri sendiri. Baginya, dengan menunjukkan rasa kesungguhan tersebut, maka akan tercipta perasaan untuk membantu ( $a$ desire to help), dan otomatis hal tersebut memicunya untuk bersikap ramah seperti memberikan senyum, dan berusaha untuk selalu mengajukan pertanyaan terhadap pengguna dengan serius. Kemudian sesuai dari apa yang telah informan pahami, menurutnya jangka waktu yang dibutuhkan oleh ia sebagai pustakawan referensi dalam menjawab informasi pengguna adalah pada kisaran 5 sampai 30 menit. Pustakawan yang mampu untuk memberikan layanan secara cepat dan tanggap akan memberikan pancaran positif dari pengguna berupa kepercayaan untuk selalu menggunakan sumber dari perpustakaan.

Kemudian informan memiliki kemampuan untuk merancang dan mengorganisasikan berbagai sumber informasi yang dapat dijadikan sebagai sumber referensi, seperti contohnya paket informasi berupa produk kemas ulang berupa $e$ newsletter dan pathfinder. Proses analisis yang mendalam terhadap sumber informasi yang dapat dijadikan rujukan juga perlu dilakukan oleh informan dalam melakukan pelayanan yang responsif. Informan selanjutnya juga mengutarakan bahwa jika menjadi pustakawan referensi, dibutuhkan sebuah ketertarikan, ketekunan, dan kerajinan. Adanya ketertarikan informan di bidang hukum, serta juga kemampuan atau kompetensinya yang memang berlatarbelakang ilmu perpustakaan membuatnya lebih mampu untuk membangun kesadaran dirinya untuk bersikap lebih kritis dalam menganalisis dan memahami sumber informasi yang tepat dan relevan sebagai bentuk kemudahan akses bagi pengguna perpustakaan. Setelah analisis terhadap berbagai sumber referensi dilakukan dan informasi yang dicari telah ditemukan dan dijawab, informan masih perlu menganalisis dan memverifikasi dengan membantu pengguna untuk mengingat informasi apa yang sesungguhnya sedang dicari secara spesifik, sehingga ia perlu untuk selalu mem-follow up pengguna.

2. Pemahaman dan Pengetahuan Sebagai Modal Dasar Utama

Mempelajari dan memahami kompleksitas dari pekerjaan referensi dibutuhkan proses pembelajaran yang lebih dari hanya sekadar pembelajaran secara formal saja. Menurut informan, proses yang perlu dilakukan oleh pustakawan yang bertugas pada layanan referensi untuk dapat memahami apa yang harus ia kerjakan minimal adalah selama 6 bulan melalui proses magang di perpustakaan besar. Hal ini dilakukan untuk memunculkan minat terhadap sumber informasi/bahan referensi dan karakteristik dari penggunanya itu sendiri, sehingga untuk membangun pengetahuan tersebut diperlukan adanya ketertarikan atau passion di bidang hukum seperti yang telah dijelaskan 
Bibliotech : Jurnal Ilmu Perpustakaan dan Informasi, 3 (2) 2018

sebelumnya. Keahlian dasar yang juga dimiliki oleh pustakawan referensi adalah kemampuannya dalam mengetahui berbagai macam sumber sebagai bahan referensi. Jenis-jenis database yang menurut informan dapat dirujuk sebagai informasi karena aksesnya yang tidak berbayar adalah seperti DOAJ, Portal Garuda, ISJD, serta One Search. Sementara itu, database yang tidak berbayar seperti hukumonline yang menyangkut sumber informasi peraturan dan putusan, Law Associated Review, Perpustakaan Nasional, dan sempat juga melanggan database jurnal seperti BIES dan Journal Law and Society dari JSTOR. Selain database, akses elektronik yang sering dirujuk sebagai sumber referensi oleh informan adalah katalog elektronik perpustakaan yang memiliki kerjasama dengan DanLev, seperti Perpustakaan KPK, Ombudsman, Komnas HAM, Perpustakaan BPHN, serta lembaga lainnya yang juga erat kaitannya dengan bidang hukum, dan atau Perpustakaan UI.

Sebagai pustakawan referensi, maka dibutuhkan sikap terbuka dan selalu memperhatikan perkembangan yang terjadi di lingkungan bidang pekerjaannya. Informan pustakawan merekomendasikan bacaan yang berasal dari forum berita dan diskusi Milis (mailing list) Hal penting lainnya yang perlu diperhatikan adalah pengembangan di bidang teknologi informasi. Informan mengakui bahwa pengembangan attitude dan responsif terhadap perkembangan teknologi yang dapat merubah kebiasaan orang karena adanya suatu teknologi baru yang lebih digandrungi oleh orang-orang tersebut sangatlah penting, sehingga mau tidak mau perpustakaan pun juga harus menyesuaikan untuk menunjang layanannya agar tetap eksis bagi pengguna. Selain itu, berdasarkan RUSA Professional Competencies, pustakawan referensi perlu aktif dalam berkontribusi untuk meningkatkan praktik kerjanya secara profesional. Menurut informan, sebagai salah satu bentuk kontribusinya adalah dengan mengikuti berbagai kegiatan untuk meningkatkan pembelajaran, memperbaharui wawasan, dan memperluas jaringannya dengan sesama profesi pustakawan. Informan kerap mengikuti pelatihan-pelatihan yang biasa diadakan oleh rekan-rekan pustakawan di organisasi Asosiasi Perpustakaan Khusus dan Perpustakaan Nasional. Informan juga berperan dalam memotivasi agar staf seperti di layanan mengikuti kegiatan pengembangan kapasitas seperti pelatihan Literasi Informasi di Johannes Oentoro Library UPH, pelatihan tesaurus di Komnas HAM, seminar di Perpustakaan Nasional, dan kegiatan-kegiatan organisasi yang diurus oleh informan pustakawan sendiri yakni ISIPII. Selesai mengikuti kegiatan pengembangan kapasitas, maka informan pustakawan pun kerap mengadakan sharing knowledge bersama dengan staf-stafnya. 
Bibliotech : Jurnal Ilmu Perpustakaan dan Informasi, 3 (2) 2018

\section{Meningkatkan Eksistensi Layanan Referensi Melalui Promosi}

Pengembangan promosi yang dilakukan di Perpustakaan Hukum Daniel S. Lev secara garis besar menurut informan terbagi kedalam dua kelompok segmentasi yakni promosi yang "eksis ke dalam" yang lebih difokuskan kepada pemberian daftar informasi kepada pengguna internal contohnya e-newsletter, pathfinders dan e-mail harian, serta promosi yang "eksis ke luar", yang menekankan untuk mengenalkan berbagai sumber daya informasi hukum yang dimiliki Perpustakaan DanLev dan acara-acara lembaga internal melalui media sosial Facebook (Daniel Lev Lawlib) dan Twitter (@danlevlibrary). Sebagian besar pengerjaan promosi ini dilakukan oleh informan staf, meski informan pustakawan tetap melakukan pengawasan dan menyalurkan konsep karena sesungguhnya merupakan bagian dari layanan referensi. Hanya saja secara tugas kerja memang dipisahkan dari kegiatan referensi.

Kegiatan promosi yang dilakukan untuk lebih memperkenalkan perpustakaan beserta sumber daya yang dimilikinya pun juga dapat memiliki manfaat salah satunya adalah perpustakaan menjadi lebih dimanfaatkan oleh pengguna. Menurut informan, dengan melakukan serangkaian promosi untuk mengenalkan sumber daya informasi yang dimiliki menggunakan suatu produk, diharapkan pengguna akan memiliki sebuah ketergantungan dan kebutuhan secara terus menerus terhadap informasi yang diakses melalui Perpustakaan DanLev itu sendiri. Secara eksistensi, perpustakaan dapat diakui oleh banyak orang dalam hal ini pengguna terlebih dimulai dari kalangan yang berasal dari kalangan internal, maupun juga eksternal. Selain pengakuan dari pengguna, tidak kalah pentingnya lagi adalah pengakuan dari lembaga lain karena perpustakaan yang telah eksis dalam menciptakan kebutuhan terhadap penggunanya. Perpustakaan DanLev pun mampu dikenal dan diakui oleh berbagai kalangan secara umum tidak terkecuali lembaga-lembaga lain di luar lembaga internal, yang kemudian digunakan sebagai jalan untuk memperoleh sumber rujukan mengenai suatu informasi. Pada akhirnya, selain akses terhadap informasi menjadi lebih banyak, jaringan pertemanan dan kerja sama pun juga menjadi lebih luas.

4. Berkolaborasi dan Menjaga Hubungan Baik dengan Berbagai Pihak

Mengembangkan jaringan maupun kolaborasi, khususnya kerja sama dengan pustakawan dari perpustakaan lain, dan ataupun dengan pengguna, staf, maupun pihak-pihak di luar bidang kepustakawanan/profesi lain juga dapat memberikan manfaat bagi pustakawan referensi di suatu perpustakaan. Menjalin kolaborasi dapat dilakukan mulai dari pengguna yang merupakan bagian dari lembaga internal, dimana 
Bibliotech : Jurnal Ilmu Perpustakaan dan Informasi, 3 (2) 2018

informan selalu mencoba untuk menciptakan situasi yang terbuka dan nyaman bagi pengguna seperti menghindari berbagai macam seperti sikap jutek. Hal ini masih terkait dengan sikap dan karakteristik approachability yang diperlukan oleh pustakawan referensi. Informan beranggapan bahwa melakukan kolaborasi dan menjalin relasi dengan pengguna bukan berarti untuk mencari muka atas dasar ketenaran, namun untuk menciptakan sebuah kedekatan terhadap pengguna. Selain itu, hal yang kerapkali informan kolaborasikan adalah bersama stafnya dalam urusan penelusuran informasi untuk mendapatkan sebuah jawaban dari pertanyaan yang diajukan oleh pengguna, seperti pendelegasian tugas untuk melakukan pencarian kepada informan staf dan melaporkan hasilnya kembali untuk dilakukan analisis lebih lanjut mengenai keabsahan sumber yang dirujuk.

Pihak luar merupakan salah satu aspek yang dapat mendukung terhadap tumbuh kembangnya suatu layanan di perpustakaan seperti berjejaring bersama perpustakaan lain (interlibrary loan) yang sebelumnya juga dibahas oleh Bopp (2000). Contoh kongkret kolaborasi antar sesama profesi yang dilakukan informan pustakawan adalah dengan menjadi pengurus inti dari organisasi ISIPII sejak tahun 2012. Menurutnya hal tersebut adalah salah satu kemampuan pustakawan referensi dalam "bersilaturahmi”, sehingga dalam 'menjaring' sumber informasi yang dibutuhkannya pun akan memiliki keuntungan dari sisi efektivitas dan efisiensi dengan melalui jalur informal yakni langsung menghubungi secara personal saja pustakawan atau perpustakaan yang dituju dan telah menjadi rekanan seprofesi untuk melakukan rujukan pada bidang hukum yang sedang dicari. Oleh sebab itu, informan memiliki prinsip bahwa dalam menjalankan tugas sebagai pustakawan, selain melakukan pekerjaan sehari-hari di kantor (Perpustakaan DanLev), pustakawan juga perlu untuk membina hubungan secara personal dengan perpustakaan/pustakawan lain. Perpustakaan yang sering dilakukan rujukan menyangkut informasi hukum oleh informan ketika melakukan kolaborasi atau interlibrary loan sebagian besar adalah perpustakaan yang memang memiliki hubungan baik dengan informan seperti Perpustakaan Mahkamah Konstitusi, Perpustakaan DPR, dan Perpustakaan Panwaslu.

Informan memaknai bahwa hubungan dan kolaborasi dengan sesama pustakawan yang telah membentuk kepercayaan, maka masing-masing pun akan timbul keterbukaan dalam berbagi pandangan, sehingga timbulah kenyamanan di masingmasing pihak dalam melakukan hubungan dan interaksi menyangkut pekerjaan secara lebih erat. Pada akhirnya, pustakawan referensi seperti informan ketika ingin mencari 
bahan bacaan, atau informasi lainnya yang melibatkan pustakawan lain didalamnya akan relatif lebih mudah dan cepat dilakukan. Selain melakukan kolaborasi dengan sesama profesi di bidang perpustakaan, menjalin hubungan secara intens dengan pihak luar pun juga dilakukan informan bersama profesi non pustakawan seperti praktisi atau peneliti di bidang hukum yang berasal dari lembaga internal. Manfaat dari memiliki kedekatan dan menjalin hubungan baik tersebut adalah informan pustakawan dapat mendiskusikan dan menentukan kata kunci dari subjek hukum apa yang sebenarnya sedang dimaksud oleh pengguna secara spesifik, sehingga informasi yang diberikan pun lebih matang karena didasarkan pada masukan-masukan yang diberikan secara langsung dari pihak yang memang telah menekuni bidang hukum tersebut.

5. Melakukan Evaluasi Layanan Referensi

Informan sendiri secara faktual masih tergolong jarang, sehingga bentuk evaluasi terhadap layanan referensi pun dilakukan berdasarkan penilaian kalangan pengguna yang selama ini menjadi klien dari layanan yang diberikan oleh informan. Penilaian terhadap layanan referensi dan pustakawan diadakan oleh pihak HRD, yang melakukan riset berdasarkan sampling terhadap 3 orang peneliti di bidang hukum yang diwawancarai untuk memberikan masukan, atau pun kritik terhadap layanan yang telah ditawarkan. Penilaian juga dilakukan pada penggunaan media layanan referensi virtual yang paling efektif digunakan di DanLev, yang hasilnya menunjukkan bahwa WhatsApp merupakan media sosial yang paling responsif digunakan pengguna, sementara e-mail berada di posisi terakhir dari keempat media yang di survei, karena proses penggunaannya yang cenderung lebih lama dan lebih formal. Secara inti, informan dalam melakukan riset atau survei kecil-kecilan mengenai penggunaan media virtual ini pun sesungguhnya bergantung pada perkembangan yang sedang terjadi di dalam layanan referensi Perpustakaan Hukum Daniel S. Lev. Terkait dengan penilaian sumber informasi, informan berperan dalam memberikan masukan kepada pimpinan yang berkepentingan dalam kepengurusan perpustakaan mengenai sumbersumber apa yang telah digunakan, serta dalam memperkenalkan sumber-sumber informasi (database jurnal) yang telah disediakan dan dapat digunakan oleh perpustakaan agar pengguna yang berasal dari lembaga internal pun juga lebih turut aktif dalam menggunakannya. 
Bibliotech : Jurnal Ilmu Perpustakaan dan Informasi, 3 (2) 2018

\subsection{Kendala yang Dihadapi Pustakawan dalam Layanan Referensi}

Di dalam melakukan komunikasi secara virtual, khususnya pada layanan referensi berbasis e-mail dan chat, pustakawan perlu memperhatikan beberapa hal penting ketika berada pada situasi wawancara dengan pengguna. Berdasarkan RUSA Guidelines for Behavioral Performance of Reference and Information Services Professionals, Ronan (2003) menyebutkan bahwa approachability, interest, formality and pacing, listening and inquiring, searching, dan follow up sangat dibutuhkan untuk meningkatkan keterampilan pustakawan dalam melakukan pelayanan referensi. Sementara itu, berdasarkan pedoman Professional Competencies for Reference and User Services Librarians (2003) yang dikeluarkan oleh American Library Association (ALA), terdapat lima kualifikasi keahlian dan kompetensi khusus yang harus dimiliki dan menjadi dasar bagi pustakawan referensi yakni Access/Akses (responsiveness, organization and design of services, critical thinking and analysis), Knowledge Base/Dasar Pengetahuan (environmental scanning, application of knowledge, dissemination of knowledge, active learning), Marketing/Promosi (assessment, communication and outreach, evaluation), Collaboration/Kolaborasi (relationship with users, relationship with colleagues, relationship within the profession, relationship beyond the library and the profession), Evaluation and Assessment of Resources and Services/Evaluasi dan Penilaian Sumber dan Layanan (user needs, information services, information resource, service delivery, information interfaces, information service providers).

Seperti yang telah diketahui sebelumnya bahwa informan yang memiliki status pustakawan tunggal di perpustakaan ini memiliki banyak tugas lain selain tugasnya pada perpustakaan khususnya di bidang layanan. Salah satunya adalah karena ketidakjelasan dalam pengambilan keputusan oleh pimpinan yakni antara PSHK, STH Indonesia Jentera, atau bahkan YSHK dalam mengkoordinasikan tugas kerja di bidang informasi pada lembaga internal tersebut menjadikan struktur kerjanya sedikit kacau dilihat pada sudut pandang manajerialnya. Hingga saat ini, informan pun selain menjadi pustakawan referensi, juga merangkap sebagai pengelola arsip, sekretaris jurnal, dan bahkan sekaligus menjadi kepala perpustakaan dan manajer pengetahuan/knowledge centre di Pusat Studi Hukum dan Kebijakan (PSHK). Selain itu informan memiliki kesibukan lainnya untuk "mengabdikan masyarakat" dalam kaitannya pada organisasi profesi pustakawan (ISIPII), yang ternyata menguras waktunya (minimal 15 jam seminggu) untuk melakukan kegiatan (rapat, seminar, pelatihan) di luar pekerjaan sehari-harinya menjadi seorang pustakawan di Perpustakaan Hukum Daniel S. Lev. Terlebih ia merupakan pimpinan/presiden dari organisasi tersebut. Dibandingkan dengan waktu kerja dan perannya di perpustakaan, ternyata masih belum 
Bibliotech : Jurnal Ilmu Perpustakaan dan Informasi, 3 (2) 2018

sebanding dengan apa yang ia lakukan untuk aktif berorganisasi di luar, dimana hal tersebut pun ia sadari bahkan sesali. Menurut informan, untuk mengembangkan layanan referensi yang pekerjaannya tergolong rumit memang tidak dapat disambi dengan pekerjaan lainnya.

Melihat tugas yang diemban oleh informan telah dikatakan mencapai overload, sehingga menyebabkan dirinya yang belum mampu dalam meningkatkan perannya serta substansi dari layanan referensi itu secara lebih lanjut. Substansi yang dalam artian meningkatkan nilai-nilai dari informasi yang ada dan mampu terakses dari beragam sumber, yang secara lebih lanjut untuk menciptakan sebuah inovasi yang dapat menjadi 'magnet', serta aset penting bagi nilai jual dari Perpustakaan Hukum Daniel S. Lev. Seperti contohnya pada produk pathfinder yang sesungguhnya dapat di kemas ulang lebih menarik, namun bagi informan belum dimaksimalkan karena sifat pembuatannya saat ini masih berbasis permintaan dari peneliti yang sedang membutuhkannya saja. Menurutnya, diperlukan inisiatif tinggi untuk dapat berinovasi dalam mengembangkan produk-produk baru yang merupakan indikator keberhasilan dari pelayanan referensi yang dilakukan oleh seorang pustakawan. Karena idealnya, pustakawan referensi dapat menjadi seseorang yang mampu berbagi pengalamannya dalam melayani kepada orang lain melalui buku atau karya tulis ilmiah lainnya sebagai media pengetahuan baru, sehingga tidak hanya sekadar melakukan kegiatan menjawab pertanyaan yang masuk dari pengguna saja.

Oleh karena padatnya kegiatan yang diemban oleh informan pustakawan, maka kebutuhan akan staf yang khusus melayani layanan referensi memang dapat menjadi hal yang juga tidak dapat terbantahkan lagi diperlukan bagi Perpustakaan Hukum Daniel S. Lev. Informan beranggapan bahwa memang tugas pada layanan referensi ini sudah harus didelegasikan secara khusus kepada staf yang melayani layanan yakni informan staf yang memang telah menjadi assistant librarian nya. Namun yang menjadi dilema adalah informan pustakawan masih merasa belum yakin untuk memberikan tanggung jawab tersebut secara penuh kepada stafnya tersebut. Salah satunya dikarenakan pendidikannya yang saat ini masih menempuh S1 Ilmu Perpustakaan di Universitas Terbuka. Sesungguhnya niat awal informan pustakawan menerima informan staf bekerja di bagian layanan adalah untuk "eksperimen", karena ia ingin melihat kualitas dan keahlian yang telah ditunjukkan semasa magang sebelumnya. Setelah waktu berjalan satu tahun (2015 akhir hingga pertengahan 2017), ternyata masih dirasa belum mampu dikarenakan pemahamannya terhadap subjek bidang hukum yang belum terlihat. Permasalahannya adalah, proses pemahaman terhadap konsep layanan referensi, serta subjek di bidang hukum sendiri memang masih belum terlihat dari informan staf. Hal ini terbukti karena informan staf pun mengakui bahwa ia memang belum 
Bibliotech : Jurnal Ilmu Perpustakaan dan Informasi, 3 (2) 2018

memiliki ketertarikan terhadap subjek bidang hukum. Meskipun ia akan tetap berusaha untuk memahami serta akan siap dan ikhlas jika ditugaskan oleh informan pustakawan untuk menjadi staf pustakawan referensi, dengan berprinsip pada "menikmati pekerjaan yang ada".

\section{KESIMPULAN}

Informan pertama sebagai pustakawan referensi mempersepsikan perannya sebagai representasi dari Perpustakaan Hukum Daniel S. Lev sendiri (library is a librarian), yang berusaha untuk menyediakan informasi di bidang hukum kepada pengguna kapan pun dan dimanapun berada tanpa dibatasi waktu dan ruang berdasarkan konsep virtual yang diusung. Hal ini didasarkan pada dirinya yang menjadi seorang "pustakawan aktivis". Dengan menciptakan akses secara luas dan mudah kepada pengguna, peran dari pustakawan dalam hal ini adalah sebagai mediator yang siap menghubungkan pengguna dengan berbagai sumber yang berada di luar dari perpustakaan DanLev. Hal ini terkait dengan sifat substantif dari layanan referensi yang merupakan buah hasil dari pemikiran dan konseptualisasi pustakawan sendiri untuk menciptakan ketergantungan dan kebutuhan mendasar pengguna akan informasi di bidang hukum. Meskipun pada akhirnya, pustakawan memang memiliki banyak tanggung jawab sebagai "aktivis" dan harus mengatur pekerjaan antara melakukan layanan referensi dengan pekerjaan lain yang secara mayoritas adalah kegiatannya dalam berorganisasi di ISIPII untuk mengeksistensikan keberadaan profesi pustakawan. Namun hingga saat ini ia tetap mampu untuk berperan dalam melakukan kegiatan referensi pada tahap research question, yang dalam prosesnya didukung juga dengan kompetensi akses, basis pengetahuan, kolaborasi, serta kompetensi lainnya seperti promosi dan evaluasi yang meskipun keduanya tidak dilakukan sepenuhnya oleh pustakawan sendiri.

Pustakawan telah mampu menjalankan perannya dalam melakukan pelayanan referensi bagi pengguna terutama yang secara aktual merupakan pengguna internal berdasarkan basis kompetensi yang ada. Meskipun di satu sisi, telah terlihat pula bahwa pustakawan referensi ini masih memiliki berbagai kendala dalam melakukan peran dan tugas tersebut. Oleh karena itu, terdapat beberapa hal yang dapat dipertimbangkan agar peran dari pustakawan serta layanan referensi di Perpustakaan Hukum Daniel S. Lev pun dapat lebih ditingkatkan seiring dengan berjalannya waktu. Salah satunya adalah dengan mengurangi waktu atau kegiatan pustakawan pada organisasi di luar tugas kerjanya di kantor (Perpustakaan DanLev), sehingga dapat memanfaatkan waktunya dengan baik untuk mengembangkan layanan referensi dan membimbing staf di bagian layanan secara lebih intensif. Kemudian merekrut staf baru yang khusus memiliki kualifikasi di bidang pelayanan referensi jika memang opsi pertama urung dilakukan, agar inovasi dalam pengembangan 
Bibliotech : Jurnal Ilmu Perpustakaan dan Informasi, 3 (2) 2018

layanan referensi pun mampu ditingkatkan secara efektif dan berkolaborasi dengan staf layanan yang sudah ada. Pertimbangan lainnya adalah menyangkut hal teknis, yakni meningkatkan promosi menyangkut database yang biasa diacu sebagai sumber referensi bagi pengguna baik melalui brosur maupun media sosial, serta diadakannya evaluasi secara terjadwal.

\section{DAFTAR PUSTAKA}

American Association of Law Libraries. (2014). Law libraries and access to justice. Diambil kembali dari http://www.aalnet.org/mm/Publications/products/atjwhitepaper.pdf

Blake, R., \& Sekuler, R. (2006). Perception (5 ${ }^{\text {th }}$ ed.). New York: McGraw-Hill.

Bopp, R.E. (2000). Reference and information services: An introduction (3 ${ }^{\text {rd }}$ ed.). Englewood: Libraries Unlimitted.

Brophy, P. (2001). The library in the twenty-first century: New services for the information age. London: Library Association Publishing.

Cassell, K.A., \& Hiremath, U. (2009). Reference and information services in the $21^{\text {st }}$ century: An introduction. London: Facet Publishing.

Creswell, J.W. (2013). Qualitative inquiry and research design: Choosing among five approaches (3rd ed). Sage Publications: California.

Katz, W.A. (1992). Introduction to reference work vol. 1 ( $6^{\text {th }}$ ed.). New York: McGraw-Hill.

Learning Centres Research Team. (2014). Trends in learning centres and library developments: 2008-2013. Diambil kembali dari https://lekythos.library.ucy.ac.cy/bitstream/handle/10797/13776/info042.pdf

Reference and User Services Librarians. (2003). Guidelines for professional competencies for reference and user services librarians. Diambil kembali dari http://www.ala.org/rusa/resources/guidelines/professional

Reference and User Services Librarians. (2004). Guidelines for implementing and maintaining virtual reference services. Diambil kembali dari http://www.ala.org/rusa/resources/guidelines/virtrefguidelines

Ronan, J.S. (2003). Chat reference: A guide to live virtual reference services. Westport: Libraries Unlimited.

Ross, C.S. (2002). Conducting the reference interview: A how to do it manual for librarians. New York: Neal-Schuman Publishers.

Undang-Undang Republik Indonesia Nomor 43 Tahun 2007 Tentang Perpustakaan. 
Bibliotech : Jurnal Ilmu Perpustakaan dan Informasi, 3 (2) 2018

Wahyuni, M. (2015). Peran pustakawan sebagai penyedia informasi. Jurnal Iqra', 9 (2), 39-

53. Diambil kembali dari http://repository.uinsu.ac.id/22/1/artikel\%25204.pdf

Walgito, B. (1980). Pengantar psikologi umum. Yogyakarta: Penerbit ANDI. 